\title{
Profesionalisme Guru Pascasertifikasi
}

\author{
Salma \\ Andis Sukri Syamsuri \\ Universitas Muhammadiyah Makassar \\ andissukrisyamsuri@unismuh.ac.id \\ Nurdin \\ Universitas Muhammadiyah Makassar \\ nurdin@unismuh.ac.id
}

\begin{abstract}
ABSTRAK
Penelitian tentang Profesionalisme Guru Pascasertifikasi di Masyarakat Kabupaten Pinrang. Rumusan masalah penelitian ini adalah Bagaimana pengaruh sertifikasi profesionalisme guru terhadap kinerja pascasertifikasi di masyarakat Kabupaten Pinrang. Penelitian ini bertujuan untuk mengetahui bagaimana pengaruh sertifikasi profesionalisme guru terhadap kinerja pascasertifikasi di masyarakat Kabupaten Pinrang. Jenis penelitian ini adalah penelitian kualitatif, pengumpulan data digunakan dengan cara observasi, wawancara mendalam, teknik dokumentasi dari hasil foto. Dan yang menjadi sasaran penelitian adalah masyarakat yang benar-benar di anggap telah mengikuti program sertifikasi guru. Responden di pilih langsung oleh peneliti melalui teknik purposive Sampling. Hasil penelitian ini menunjukkan bahwa kinerja guru sebelum sertifikasi belum begitu maksimal dalam membuat perangkat pembelajaran yaitu Silabus dan RPP, ketika mengajar para guru masih menggunakan metode ceramah, belum menggunakan media pembelajaran dan strategi pembelajaran, sehingga kurang inovasi kreatifitas mengembangkan pembelajaran karena hanya terpaku pada metode, strategi dan media yang sudah sering di lakukan. Tetapi setalah sertifikasi kinerja guru dikatakan meningkat karena dapat dilihat bahwa para guru membuat Silabus dan RPP secara mandiri, menggunakan strategi dalam metode pembelajaran ketika proses belajar mengajar, menggunakan metode pembelajaran agar siswa lebih mudah memahami materi pelajaran yang dimiliki serta dapat meningkatkan kesejahteraan para guru karena adanya tunjangan profesi tersebut.
\end{abstract}

\section{Kata Kunci : Profesionalisme Guru, Pascasertifikasi}

\section{PENDAHULUAN}

Seiring dengan berkembangnya ilmu pengetahuan dan teknologi yang semakin pesat dalam berbagai aspek kehidupan telah membawa dampak terhadap pola pikir masyarakat akan pentingnya kualitas sumber daya manusia. Pendidikan sebagai salah satu aspek yang memberikan kontribusi besar dalam menghasilkan manusia yang berkualitas dan memiliki peranan penting dalam mengembangkan sumber daya manusia yang diperlukan bagi pembangunan di semua kehidupan bangsa. Mengingat demikian pentingnya pendidikan dalam menciptakan sumber daya manusia yang berkualitas dan professional, salah satu sumber daya manusia ( SDM ) dalam pendidikan adalah guru. Oleh karena itu, upaya perbaikan apapun yang di lakukan untuk meningkatkan kualitas 
pendidikan tidak akan memberikan sumbangan yang signifikan tanpa di dukung oleh guru yang professional. Karena profesionalisme guru sebagiannya dikaitkan dengan persoalan mutu pendidikan yang bahwa guru merupakan salah satu factor dominan yang mempengaruhi belajar siswa. Karena alasan inilah maka pemerintah selalu berupaya keras untuk meningkatkan mutu guru mulai dari peningkatan kualifikasi guru sampai kepada standardisasi profesionalisme guru melalui program sertifikasi guru.

Undang - undang RI Nomor 20 Tahun 2003, Undang - undang RI Nomor 14 Tahun 2005 dan peraturan pemerintah Nomor 19 Tahun 2005 mengamatkan bahwa guru wajib memiliki kualifikasi akademik, kompetensi, sertifikat pendidik, sehat jasmani dan rohani, serta memiliki kemampuan untuk mewujudkan tujuan pendidikan nasional. Persyaratan akademik guru adalah S1/D-IV yang dibuktikan dengan ijasah sesuai dengan jenis, jenjang, dan satuan pendidikan formal di tempat penungasan. Persyaratan kompetensi guru mencakup penguasaan kompetensi pedagogic, professional, kepribadian, dan sosial yang dibuktikan dengan sertifikat pendidik yang di peroleh melalui sertifikasi.

Seharusnya guru - guru yang telah melaksanakan sertifikasi diharapkan bisa menjadi guru yang profesional, bisa mengajar dengan baik, bisa mengembangkan ilmu pengetahuan yang dimilikinya, dapat menjunjung tinggi profesi guru sehingga profesi guru akan lebih dihargai dan tidak di remehkan lagi. Dan dapat memperbaiki kinerja mereka dalam pembelajaran di sekolah dimana guru tersebut mengajar. Yang menjadi sorotan masyarakat sekarang adalah masih banyaknya guru - guru yang di anggap tidak professional dan tidak memperbaiki kinerjanya dalam melaksanakan tugasnya sebagai pendidik yang jelas - jelas telah melakukan sertifikasi. Karena percuma sekali jika pemerintah telah banyak mengeluarkan dana untuk program sertifikasi akan tetapi hasilnya nihil belaka.

\section{KAJIAN TEORI}

"Profesionalisme", adalah sebutan yang mengacu kepada sikap mental dalam bentuk komitmen dari para anggota suatu profesi untuk senantiasa mewujudkan dan meningkatkan kualitas profesionalnya. Seorang guru yang memiliki profesionalisme yang tinggi akan tercermin dalam sikap mental serta komitmennya terhadap perwujudan dan peningkatan kualitas profesional melalui berbagai cara dan strategi. Ia akan selalu mengembangkan dirinya sesuai dengan tuntutan perkembangan zaman sehingga keberadaannya senantiasa memberikan makna professional. Dalam konteks guru, makna profesionalisme sangat penting karena profesionalisme akan melahirkan sikap terbaik 
bagi seorang guru dalam melayani pendidikan peserta didik, sehingga kelak sikap ini tidak hanya memberikan manfaat bagi siswa, tetapi juga memberikan manfaat bagi orang tua, masyarakat, dan institusi sekola itu sendiri. Jadi pada prinsipnya profesionalisme guru dapat diartikan sebagai guru yang dapat menjalankan tugasnya secara professional.

Menghadapi tantangan demikian, maka diperlukan guru yang benar - benar professional. Paling tidak ada empat cirri utama agar seorang guru terkelompok kedalam guru yang profesional, yakni: (1) Memiliki kepribadian yang matang dan berkembang (2) Mempunyai keterampilan membangkitkan minat peserta didik (3) memiliki penguasaan ilmu pengetahuan dan teknologi yang kuat (4)Sikap profesionalnya berkembang secara berkesinambungan. Sedangkan menurut peraturan pemerintah No 19 Tahun 2005 tentang Standar Nasional Pendidikan bahwa kompetensi guru professional terbagi menjadi empat kompetensi guru yaitu (1) Kompetensi pedagogic adalah pedagogik yang harus dikuasai guru meliputi pemahaman guru terhadap peserta didik, perencanaan danpelaksanaan pembelajaran, evaluasi hasil belajar, dan pengembangan peserta didik untuk mengaktualisasikan berbagai potensi yang dimilikinya. (2) Kompetensi kepribadian adalah kemampuan personalyang mencerminkan kepribadaian yang mantap, stabil, dewasa, arif, berakhlak mulia dan beribawa, dan kemudian dapat menjadi teladan bagi peserta didik. (3) Kompetensi sosial adalah kemampuan yang harus dimiliki guru untuk berkomunukasi dan bergaul secara efektif dengan peserta didik, tenaga kependidikan, orang tua / wali peserta didik dan masyarakat sekitar. Dan (4) Kompetensi professional adalah penguasaan materi pembelajaran secara luas dan mendalam yang harus dikuasai guru mencakup penguasaan materi kurikulum mata pelajaran disekolah dan subtansi keilmuan yang menaungi materinya, serta penguasaan terhadap struktur dan metodologi keilmuannya. Dalam UU Nomor 14 Tahun 2005 tentang Guru dan Dosen (Pasal 1) dinyatakan bahwa : "Guru adalah pendidikan profesional dengan tugas utama mendidik, mengajar, membimbing, mengarahkan, melatih, menilai dan mengevaluasi peserta didik pada jalur pendidikan formal, pada jenjang pendidikan dasar dan pendidikan menengah". Guru memengang peranan yang sangat strategis terutama dalam membentuk watak bangsa serta mengembangkan potensi siswa. Kehadiran guru tidak tergantikan oleh unsur yang lain, lebih - lebih dalam masyarakat kita yang multikultural dan multi dimensinsional, dimana peranan teknologi untuk menggantikan tugas - tugas guru sangat minim. Guru memiliki peranan yang sangat penting dalam menentukan keberhasilan pendidikan. Guru yang professional diharapkan menghasilkan lulusan yang berkualitas. Profesionalisme guru sebagai ujung tombak di dalam implementasi kurikulum di kelas 
yang perluh mendapat perhatian. (Depdiknas, 2005). Tugas guru secara garis besar meliputi empat hal yaitu tugas profesi, tugas keagamaan, tugas kemanusiaan dan tugas kemasyarakatan.

Guru professional mempunyai peranan penting dalam kegiatan belajar mengajar, karena hitam putihnya proses belajar mengajar di dalam kelas banyak dipengaruhi oleh mutu guru itu sendiri. Berkaitan dengan masalah pendidikan, maka kinerja guru merupakan salah satu faktor yang akan sangat menentukan terhadap kualitas proses dan hasil pendidikan. Guru merupakan profesi profesional di mana ia dituntut untuk berupaya semaksimal mungkin menjalankan profesinya sebaik mungkin. Sebagai seorang profesional maka tugas guru sebagai pendidik, pengajar dan pelatih hendaknya dapat berimbas kepada siswanya. Dalam hal ini guru hendaknya dapat meningkatkan terus kinerjanya yang merupakan modal bagi keberhasilan pendidikan. Seorang guru yang professional harus memiliki sertifikat pendidik (sertifikasi guru) setelah lulus uji kompetensi yang diselenggarakan oleh lembaga sertifikasi.

Sertifikasi berasal dari kata certification yang artinya diploma atau pengakuan secara resmi kompetensi seseorang untuk memangku jabatan profesional. Istilah sertifikasi dapat diartikan sebagai surat keterangan (sertifikat) dari lembaga berwenang yang diberikan kepada profesi, dan sekaligus sebagai penyataan (lisensi) terhadap kelayakan profesi untuk melaksanakan tugas. Bagi guru agar dianggap layak dalam mengembang tugas profesi pendidik, maka ia harus memiliki sertifikat pendidik. Sertifikat pendidik diberi kepada guru dan dosesn yang telah memenuhi persyaratan. Sertifikasi tersebut dapat diikuti oleh guru dalam jabatan yang telah memiliki kualifikasi akademik sarjana (S1) atau diploma empat (D-IV). Menurut Undang-Undang Nomor 14 Tahun 2005 Tentang Guru dan Dosen Pasal 1 Ayat (11) disebutkan bahwa sertifikasi adalah proses pemberian sertifikat pendidik kepada guru dan dosen. Peraturan Pemerintah Republik Indonesia Nomor 74 Tahun 2008 tentang Guru (2008: 4) pasal 1 menjelaskan bahwa “(1) sertifikasi adalah proses pemberian sertifikat pendidik untuk guru, (2) sertifikat pendidik adalah bukti formal sebagai pengakuan yang diberikan kepada guru sebagai tenaga profesional". Sedangkan sertifikat pendidik adalah bukti formal sebagai pengakuan yang diberikan kepada guru dan dosen sebagai tenaga professional. Menurut E. Mulyasa (2008: 33), "sertifikasi guru adalah suatu proses pemberian pengakuan bahwa seseorang telah memiliki kompetensi untuk melaksanakan pelayanan pendidikan pada satuan pendidikan tertentu, setelah lulus uji kompetensi yang diselenggarakan oleh lembaga sertifikasi”. Tujuan dan Manfaat Sertifikasi Guru yaitu tujuan sertifikasi guru 
adalah Sertifikasi dilakukan untuk menentukan kelayakan guru dalam melaksanakan tugas sebagai agen pembelajaran dalam rangka mewujudkan tujuan pendidikan nasional, sertifikasi juga dilakukan untuk meningkatkan mutu proses dan hasil pendidikan, sertifikasi untuk meningkatkan martabak guru dan sertifikasi untuk meningkatkan profesionalisme guru. Sedangkan manfaat dari sertifikasi guru yaitu melindungi profesi guru dari praktik - praktik yang tidak kompeten yang dapat merusak citra profesi guru itu sendiri, melindungi masyarakat dari praktik - praktik pendidikan yang tidak berkualitas dan tidak professional yang akan dapat menghambat upaya peningkatan kualitas pendidikan dan penyiapan sumber daya manusia, Menjadi wahana penjaminan mutu bagi lembaga pendidikan tenaga kependidikan (LPTK) yang bertugas mempersiapkan calon guru dan juga berfungsi sebagai control mutu bagi pengguna layanan pendidikan dan Memperoleh tunjagan profesi guru yang lulus ujian sertifikasi serta meningkatkan kesejahteraan guru.

Salah satu cara untuk meningkatkan profesionalisme guru dengan memenuhi kebutuhannya dengan hal tersebut dapat memotivasi seorang guru untuk memperbaiki dan meningkatkan kinerja dalam melaksanakan tugasnya sebagai pendidik. Menurut Teori motivasi dua faktor atau teori iklim sehat oleh Herzberg yaitu cara terbaik untuk memotivasi seseorang adalah dengan memenuhi kebutuhan tingkat tingginya. Herzberg mengatakan bahwa memberikan seseorang kenaikan gaji atau kondisi kerja yang baik dan dapat memotivasinya karena kebutuhan tingkat rendah dapat dipenuhi secara cepat. Implikasi teori ini ialah bahwa seorang pekerja mempunyai persepsi berkarya tidak hanya sekedar mencari nafkah, akan tetapi sebagai wahana untuk memuaskan berbagai kepentingan dan kebutuhannya, bagaimanapun kebutuhan itu dikategorisasikan. Sedangkan menurut Maslow's Need Hierarchy Theory oleh Abraham Maslow kebutuhan dapat didefinisikan sebagai suatu kesenjangan atau pertentangan yang di alami antara suatu kenyataan dengan dorongan yang ada dalam diri. Apabila pegawai kebutuhannya tidak terpenuhi maka pegawai tersebut akan menunjukkan perilaku kecewa. Sebaliknya, jika kebutuhannya terpenuhi maka pegawai tersebut akan memperlihatkan perilaku yang gembira sebagai manifestasi dari rasa puasnya. Abraham Maslow mengemukakan bahwa hierarki kebutuhan manusia adalah sebagai berikut: (1) Kebutuhan fisiologis, yaitu kebutuhan untuk makan, minum, perlindungan fisik, bernafas, seksual. Kebutuhan ini merupakan kebutuhan tingkat terendah atau disebut pula sebagai kebutuhan yang paling dasar. (2) Kebutuhan rasa aman, yaitu kebutuhan akan perlindungan dari ancaman, bahaya, pertentangan, dan lingkungan hidup. (3) Kebutuhan untuk rasa memiliki, yaitu 
kebutuhan untuk diterima oleh kelompok, berafiliasi, berinteraksi, dan kebutuhan untuk mencintai serta dicintai. (4) Kebutuhan akan harga diri, yaitu kebutuhan untuk dihormati dan dihargai oleh orang lain. (5) Kebutuhan untuk mengaktualisasikan diri, yaitu kebutuhan untuk menggunakan kemampuan, skill, dan potensi. Kebutuhan untuk berpendapat dengan mengemukakan ide-ide memberi penilaian dan kritik terhadap sesuatu.

\section{METODE PENELITIAN}

Jenis penelitian yang digunakan dalam penelitian mengenai Profesionalisme Guru Pascasertifikasi di Masyarakat Kabupaten Pinrang ini adalah penelitian kualitatif. Jenis penelitian yang digunakan adalah metode penelitian kualitatif yakni penelitian yang digunakan untuk meneliti pada kondisi obyek yang alamiah dimana peneliti adalah sebagai instrument kunci yang bertujuan untuk memahami bagaimana profesionalisme guru pascasertifikasi di masyarakat Kecamatan Lembang Kabupaten Pinrang. Informan ditentukan dengan teknik purposive sampling, teknik pengumpulan data yaitu observasi, wawancara dan dokumentasi, kemudian dianalisis melalui tahapan yaitu reduksi data (data reduction), paparan data (data display), paparan data (data display), dan penarikan kesimpulan dan verifikasi (conclusion drawing/ verifying), menggunakan teknik keabsahan data triangulasi sumber, waktu dan teknik. Dan menggunakan pencapaian tujuan karena dalam sebuah penelitian, peneliti harus mengetahui betul apa permasalahan yang hendak diteliti, apa tujuan dari penelitian tersebut dan mencari data - data yang dapat mendukung tercapainya atau berhasilnya penelitian tersebut.

\section{PEMBAHASAN}

Pada prinsipnya profesionalisme guru dapat diartikan sebagai guru yang dapat menjalankan tugasnya secara professional. Dalam UU Guru dan Dosen (pasal 1 ayat 4) disebutkan bahwa professional adalah pekerjaan atau kegiatan yang dilakukan seseorang dan menjadi sumber penghasilan kehidupan yang memerlukan keahlian, kemahiran, atau kecakapan yang memenuhi standar mutu atau norma tertentu serta memerlukan pendidikan profesi. Profesionalisme guru akan melahirkan sikap terbaik bagi seorang guru dalam melayani kebutuhan pendidikan peserta didik melalui berbagai cara dan strategi agar dapat meningkatkan profesionalismenya salah satunya dengan menempuh program sertifikasi guru. Dengan adanya program sertifikasi dari pemerintah di bidang pendidikan menjadikan para guru sebagai pengajar dapat meningkatkan 
kinerjanya dengan standar yang telah ditetapkan. Dan kinerja guru dalam mengelolah proses pembelajaran dapat meningkat pula. Karena guru yang telah tersertifikasi mendapatkan pelatihan - pelatihan dalam rangka pengembangan dan peningkatan dalam melaksanakan tugasnya sebagai pendidik. Para guru yang ada di Kecamatan Lembang Kabupaten Pinrang yang telah mengikuti program sertifikasi guru, menunjukkan dari hasil penelitian bahwa dengan adanya pelatihan - pelatihan yang diikuti para guru yang telah tersertifikasi membawa banyak pengaruh terhadap kinerja guru dalam melaksanakan tugas sebagai pendidik.

Dari analisis di atas memperlihatkan bahwa pengaruh sertifikasi terhadap kinerja guru yang telah melaksanakan sertifikasi yaitu mereka selalu berupaya meningkatkan mutu professional mereka. Dilihat dari kesiapan mereka menguasi bahan ajar/materi yang akan diajarkan. Kemampuan mereka dalam mengembangkan materi dengan hal - hal yang menunjang seperti metode, strategi, media sampai ilmu-ilmu yang dihubungkan pada materi yang hendak mereka ajarkan. Mereka sudah lebih disiplin dibandingkan dengan sebelum sertifikasi guru. Mereka di tuntun untuk melengkapi dokumen-dokumen seperti silabus dan RPP yang sudah menjadi kewajiban mereka sebelum proses pembelajaran berlangsung. Dan juga adanya peningkatan yang terbilang memuaskan yang dialami para guru yang telah mengikuti program sertifikasi guru dalam setiap proses pembelajaran yang dilaksanakan. Karena mereka disini selalu meningkatkan mutu profesionalnya, dilihat dari kesiapan mereka menguasai bahan ajar atau materi dengan menggunakan berbagai macam metode, strategi, dan medi pembelajaran yang telah di sebutkan didalam rencana pelaksanaan pembelajaran (RPP) yang mereka dapatkan dari pelatihan - pelatihan setelah melaksanakan program sertifikasi guru. Karena dulu sebelum melaksanakan program sertifikasi guru hanya terpaku pada metode ceramah, diskusi dan tanya jawab saja.

Karena itu untuk mencapai kinerja guru yang tinggi dan maksimal setiap proses pembelajaran yang dilaksanakan, diperlukan adanya motivasi dari guru tersebut untuk meningkatkan kinerjanya secara utuh. Karena seorang guru akan berhasil jika guru tersebut mempunyai motivasi dalam kerja. Tinggi rendahnya motivasi seorang guru akan mempengaruhi keberhasilan dalam proses pendidikan dan akan berpengaruh pada kinerja guru tersebut. Motivasi yang tinggi tentunya akan menciptakan prestasi kerja atau kinerja yang tinggi pula, begitu pun sebaliknya jika motivasi rendah maka akan menciptakan prestasi kerja atau kinerja guru yang rendah. Semua itu akan berpengaruh jika kebutuhan guru terpenuhi secara maksimal. Sehingga akan menghasilkan sesuai standar yang telah 
ditetapkan. Berkaitan dengan pandangan Teori motivasi dua faktor atau teori iklim sehat oleh Herzberg, tentang cara terbaik untuk memotivasi seseorang adalah dengan memenuhi kebutuhan tingkat tingginya. Yaitu memberikan seseorang kenaikan gaji atau kondisi kerja yang baik, yang dapat memotivasinya karena kebutuhan tingkat rendah dapat di penuhi secara cepat. Dalam teori motivasi Herzberg, faktor-faktor motivator meliputi: prestasi, pengakuan, tanggungjawab, kemajuan, pekerjaan itu sendiri dan kemungkinan berkembang. Dan juga berkaitan dengan pandangan Abraham Maslow, yang mengemukakan bahwa suatu motivasi akan berpengaruh terhadap kinerja guru tersebut. Dengan kata lain, apabila motivasi kerja guru tersebut rendah atau tidak terpenuhi kebutuhannya maka pengaruh terhadap kinerja yang dihasilkannya pun rendah atau tidak maksimal. Sebaliknya juga, apabila motivasi kinerja guru tersebut tinggi atau terpenuhi kebutuhannya maka pengaruh terhadap kinerja yang dihasilkannya pun tinggi atau maksimal. Karena pengaruh sertifikasi profesionalisme guru terhadap kinerja pascasertifikasi yaitu adanya tunjangan profesi yang di berikan pemerintah lewat program sertifikasi guru kepada guru yang telah memiliki sertifikat pendidik, dengan hal tersebut sangat berpengaruh terhadap kinerja guru dalam melaksanakan tugas sebagai pendidik. Karena setelah adanya tunjangan profesi tersebut, kebutuhan ekonomi para guru jelas sudah terpenuhi, sehingga mereka dapat meningkatkan profesionalismenya sebagai pendidik dan memberikan secara maksimal setiap proses pembelajaran yang dilaksanakan. Karena lewat program sertifikasi yang dilaksanakan, selain pemerintah bermaksud ingi meningkatkan profesionalisme guru, juga ingin meningkatkan taraf hidup guru. Bentuk peningkatan kesejahteraan guru berupa tunjangan profesi sebesar satu kali gaji pokok bagi guru yang telah memiliki sertifikat pendidik. Tunjangan profesi itu diperlukan sebagai syarat mutlak sebuah profesi agar penyandang profesi dapat hidup layak dan memadai. Sehingga dapat meningkatkan kesejahteraan hidup guru maupun dalam melaksanakan tugasnya sebagai pendidik. Sedangkan menurut Abraham Maslow mengemukakan bahwa hierarki kebutuhan manusia adalah kebutuhan fisiologis, kebutuhan rasa aman, kebutuhan rasa memiliki, kebutuhan akan harga diri, dan kebutuhan mengaktualisasikan diri. Apabila hirerarki kebutuhan manusia tersebut terpenuhi, maka akan muncul motivasi dalam melakukan atau meningkatkan kinerja dalam melaksanakan tugasnyan. Namun apabila kebutuhannya tidak terpenuhi maka akan muncul atau menunjukkan perilaku kekecewaan (penurunan kinerja). Adapun bagi seorang guru, kinerja merupakan fungsi dari kemampuan dan motivasi. Jika salah satu fungsi mengalami peningkatan atau penurunan maka fungsi lainnya akan berubah. 


\section{KESIMPULAN}

1. Sertifikasi berpengaruh terhadap kinerja guru dengan melihat adanya peningkatan pada kinerja guru setelah lulus sertifikasi misalnya, setelah sertifikasi guru menjadi lebih rajin, lebih disiplin, dan selalu berusaha meningkatkan kemampuan yang dimilikinya, selalu berusaha dengan segala cara agar nilai yang diperoleh peserta didik dapat meningkat setiap proses pembelajaran yang dilaksanakan. Indikator yang ditunjukkan oleh guru telah lulus sertifikasi adalah membuat rencana pelaksanaan pembelajaran dan silabus untuk satu semester secara mandiri. Menggunakan strategi dalam metode pembelajaran ketika proses belajar mengajar. Menggunakan metode pembelajaran agar siswa lebih mudah memahami materi pelajaran yang dimiliki.

2. Kinerja guru sebelum sertifikasi belum begitu maksimal dalam melengkapi dokumen-dokumen seperti pembuatan Silabus dan RPP. Karena sebelum sertifikasi hal yang paling terlihat dalam ketidakprofesionalan guru sebelum sertifikasi ialah pada saat pembutan RPP, ketika mengajar para guru masih menggunakan metode ceramah, belum menggunakan media pembelajaran dan strategi pembelajaran setiap ingin melaksanakan proses pembelajaran.

3. Setelah adanya program sertifikasi guru yang dilaksanakan, para guru dapat meningkatkan kesejahteraan dalam kehidupan sehari - hari yang layak dan memadai karena adanya tunjangan profesi yang diberikan.

\section{DAFTAR PUSTAKA}

Danim, Sudarwan. (2010). Profesionalisasi dan Etika Profesi Guru. Bandung: Alfabeta

Djamarah, S. B. (1994). Prestasi Belajar dan Kompetensi Guru. Surabaya: Usaha Nasional

Daryanto. (2009). Panduan Proses Pembelajaran Kreatif \& Inovatif ( Teori dan Praktik dalam Pengembangan Profesionalisme Guru). Jakarta: AV Publisher

Gunawan Iman. (2013). Metode Penelitian Kualitatif. Jakarta: Bumi Aksara

Hasanah, Nur. Makalah Teori David Mcclelland, (Online). Dari Http://izulblogs. blogspot.com/2010/04/teori-motivasi-kebutuhan-david-mcclelland. html ( Diakses : 10 April 2015, Pukul: 20.15 WITA )

Muslich, Mansur. (2007). Sertifikasi Guru Menuju Profesionalisme Pendidik. Jakarta: PT Bumi Aksara.

Mulyasa, E. (2008). Standar Kompetensi dan Sertifikasi Guru. Bandung: PT Remaja Rosdakarya 
Nur, Hidayath, Irfan. (2013). Profesionlisme Guru Pai Pasca Sertifiksi. (Online).

Dari http://repository.uinjkt.ac.id/dspace/bitstream/123456789/24276/1/Irfa n\%20Nur\%20Hidayat.pdf. ( Diakses 19 April 2015, Pukul: 10.35 WITA )

Payong, Marselus, R. (2011). Sertifikasi Profesi Guru. Jakarta: PT Ideks.

Peraturan Pemerintah Republik Idonesia Nomor 19 Tahun 2005 tentang Standar Nasional Pendidikan.

Saondi, Ondi. \& Aris Suherman. (2012). Etika Profesi Keguruan. Bandung: PT Refika Aditama

Sugiyono. (2013). Metode Penelitian Kuantitatif, Kualitatif, dan R\&D. Bandung: Alfabeta.

Sugiyono. (2015). Metode Penelitian Pendidikan (Pendekatan Kuantitatif, Kualitatif, dan $R \& D)$. Bandung: Alfabeta CV.

Suyanto \& Asep Djihad. (2012). Bagaimana Menjadi Calon Guru da Guru Profesional. Yogyakarta: Multi Pressindo.

Tim Penyusun FKIP Unismuh. (2013). Pedoman Penulisan Skripsi. Makassar: Panrita Press Unismuh Makassar

Undang - Undang Republik Indoesia Nomor 14 Tahun 2005 tentang Guru dan Dosen

Undang - Undang Rebublik Indonesia Nomor 20 Tahun 2003 tentang Sistem Pendidikan Nasioanal. 